\title{
COVID-19 and Governance in Mizoram: Issues and Challenges
}

\author{
Lalhruaitluangi Sailo \\ Research Scholar, Department of Political Science, School of Social Sciences, Mizoram University, Aizawl, \\ Mizoram, India.
}

\begin{abstract}
Background: The phenomenon of COVID-19 has remained a mystery to mankind. It is not just about the disease but has also multiple ripple effects on every aspect of life. It has completely changed the course of living in a short period. The entry of Covid-19 has taken a heavy toll on human beings in particular and on every government and institution in general. Hence, for the survival and safeguard of the human race, various governments came up with protocols and measures against the spread of Covid19. Apparently, lockdown is one of the strategies widely adopted by the governments as a means to overcome the Covid-19 issue. Although, being under the same umbrella, there are countries that are worst affected by Covid19 while some countries do not face as much. No doubt that the virus has reached every nook and corner of the globe, as a matter of fact Mizoram which is situated at the corner of most of North-East India has also been under the distress of Covid-19
\end{abstract}

Aim: The study examined and understands governance on Covid19 in Mizoram. It stresses how the government and various organizations had given efforts in this situation and how the policy being adopted by them has had an impact on the people so far. It also emphasises the issues and challenges of governance policy on Covid-19 for further references.

Methods and Materials: The study was descriptive while data is collected from both primary and secondary sources. Primary sources were based on empirical analysis and questionnaire collected through online survey method while secondary sources include articles, journals, newspapers and internet. Findings are based on an online survey method that was conducted with a sample size of 500 and the universe of the study is Aizawl, Mizoram.

Results: Findings of the study have suggested that there is a lack of efficiency in carrying out the governance policy on COVID-19. Although, studies have shown that the setting up of Task Force initiated by the government and their contribution and involvement in the governance is considered remarkable.

Conclusion: After all, COVID-19 is assumed to exist long enough along with human beings, therefore, for the survival of an individual, one needs to work and function daily. Thus, by keeping that in mind, Mizoram in particular where the economy is weak and not selfsufficient, the State government and official experts have to adopt new methods and strategies besides "lockdown" for the well-being of the people.

Keywords: COVID-19, Lockdown, Government, Civil Society Organisations (CSOs), Task Force, Governance, Standard Operating Procedure (SOP)

\section{INTRODUCTION}

With the outbreak of the global pandemic of Coronavirus also known as Covid19 in early 2020, various countries and governments have taken initiatives to fight against this pandemic. Precautionary measures fall in the hands of every government to prevent and safeguard the lives of its people against this virus. So far, the Covid-19 pandemic has been one of the most catastrophic periods experienced by the world in the $21^{\text {st }}$ century. Preparations and awareness are somehow difficult for every government as it has taken the world in an un-expecting manner and also a new 
thing to everyone, even for the scientists. Countries are taking unprecedented measures to combat the spread of disease while ameliorating its pernicious effect on the economy and labour market. ${ }^{(1)}$ As of 30 January 2020, the World Health Organization (WHO) have declared this virus as a global pandemic following the announcement of the name of the disease caused by the new outbreak of coronavirus as COVID-19 on 11 February 2020. ${ }^{(2)}$ As per the instructions issued by the concerned, the safeties way is to shut down all activities and social gatherings which envisages that lockdown is the pre-requisites measure against the spread of this virus.

Hence, the world has been in a lockdown period for about two months. Covid-19 has inevitably enveloped the world, it has become a national disaster for every nation. As it is evident that Covid-19 has taken its shape in the form of the first wave since March 2020 and the Second wave since early 2021 . The unfortunate loss of many lives and the alarmingly increasing rate of Covid19 cases has led to a frantic call for all. In this scenario, the surge of the Covid19 pandemic has urged the governments to take effective measures and safety protocols for the people. Each country handled the COVID19 differently, leading to different consequential forms of the pandemic. ${ }^{(3)}$ Some countries delayed government intervention in the expectation of achieving community-based immunization. In contrast, some countries took a sharp response by locking down international borders and domestic movements. While, some countries respond by approaching with special operating procedures (SOPs), social distancing and smart tracking of the COVID19 incidence that allows businesses to continue.

At present, millions of lives have been lost and still counting. As per report on World meters, global covid19 cases201,063,706 while deaths- 4,271,347 with $181,053,540$ recovered recorded as on August 5 2021. ${ }^{(4)}$ USA, India and Brazil are the worst affected countries in the world due to Coronavirus. In this tiring period, scientists, doctors and several governments are pushing hard to develop vaccines soon. As a result, with their constant efforts and endeavours, the breakthrough of the covid19 vaccine has been announced. By mid-2021, these vaccines have been shipped across nations to protect and prevent human beings against the virus. Today, most developed countries are somewhat back to normal life with the help of vaccines although Covid19 has been lingering.

\section{India Scenario}

With a population of 1.3 billion people, India is also experiencing a crisis due to the pandemic. Having been said with lockdown the Indian government have also responded to nationwide lockdown on $24^{\text {th }}$ March 2020, to control the pandemic as countries around the globe are seeing lockdown and social distancing as a major solution to stop the spread of Covid 19. ${ }^{(5)}$ Soon, it has become a national interest, the Central government has issued certain protocols and guidelines such as shutting down institutions, public meeting places and other restrictions that are intended to contain the spread of the virus. To overcome the 'greatest emergency since Independence', the Government of India has announced a variety of measures to tackle the situation, from food security and extreme funds for healthcare to sector-related incentives and tax deadline extensions. ${ }^{(6)}$ In the initial stages, the Central government has also initiated a policy by setting up screening points in various areas, state cross line territories and airports and lockdown of international borders to prevent the spread of Covid19. Regardless, the first wave of Covid-19 has brought massive widespread of active cases and deaths across the nations. Despite being in a lockdown period for approximately 2 months, different states and Union territories have shown mixed trends of COVID-19 cases over the period. (7)

Meanwhile, by mid-September 2020, the Indian government has based its 
optimism due to a sharp drop in reported cases. Thus, it is likely believed that India is clear from the dilemma of Covid-19. This illustration has made the whole nation at ease, by letting their guard down, although cases are still prevailing. Experts have believed that the Indian government appears to let its guard down quite too soon by declaring victory over the virus. ${ }^{(7)}$ The First wave of covid19 was just the tip of the iceberg for India as the situation began to unravel as India was in the grips of a devastating second wave of Covid-19, while election campaigning had begun in full swing with no safety protocols and social distancing. ${ }^{(7)}$ Besides new variant called the Delta virus has been found in India. As a result, India has to face a fresh lockdown again by mid-April 2021, the government is fuelled with a public health emergency, due to poor preparedness and soon India started recording more than 270,000 cases with over 16,000 deaths within a single day. ${ }^{(8)}$ This turns out to be a significant turning point for the Government of India. The governance policy adopted by the Indian government during Covid- 19 has led to a miserable situation. There is no strategic plan to overcome the virus despite keeping aside the warnings and instructions about the second wave given by the experts. The government has let down its guard too soon by organising election campaigns, rallies, religious gatherings and so on which resulted in a more inevitable crisis to the nation.

Nevertheless, by mid of June, the country has witnessed more recovery with the initiatives undertaken by the government. It has taken efforts in giving out vaccines to the citizens and priorities for health care facilities and infrastructure. At present, India has given out $37,55,115$ vaccines to its citizens and this is increasing.

(9) Critics have pointed out that the Indian government is not proactive in responding to the pandemic, which has led to huge loss of lives, and also their response on Covid19 is quite too late. India is one of the worst affected countries in the world, has recorded total cases of $31,810,782$, deaths- 426,321 and recovered-30,967,223 as of August 5, 2021. ${ }^{(10)}$

\section{Covid-19 and Mizoram}

At the outset, the government of Mizoram have responded to Covid19 accordingly as per the guidance of the Central government. It has taken the situation under control where protocols and awareness have been given out extensively. Besides total lockdown, the government has locked its border areas and set up screening points in certain areas and its airport to prevent the entry of Covid-19. Till May 2020, Mizoram has only one active case reported, however, it soon started indulging with active cases when stranded Mizo's from outside the State started entering Mizoram. Soon, the government promptly set up Referral Hospital, ZMC as a dedicated Covid19 care hospital and also extended opening quarantine centres in several areas. During $1^{\text {st }}$ wave of Covid19, unlike other major States and cities in India, Mizoram has recorded the least number of covid19 cases. Under the first wave of Covid-19 (March 2020- March 2021) Mizoram has recorded 4,476 total cases which are $21.84 \%$ of the overall cases being recorded. ${ }^{(11)}$

The State Government has also taken initiatives in importing Covid19 testing laboratories such as RT-PCR, True Nat and RAgt. The government have issued Standard Operating Procedures (SOPs) under State Disaster Management Authority which has frequently revised the SOPs from time to time, as the State is being under lockdown situation now and then. Gradually, as the government issued certain relaxations in SOPs on Covid19, the situation began to unravel with the report of deaths due to the virus-related and later on active cases appears to show increasing rate with addition to deaths. The gist to the protocols of the Indian government, the State government have also relaxed the situation in responding to Covid19 issues by 
taking off certain restrictions imposed in the State before the $2^{\text {nd }}$ wave of Covid-19.

There has been a paradigm shift in the $2^{\text {nd }}$ wave when the Indian government faced zero preparedness. So, is the case with State governments and Mizoram is no exception to this. The State is facing enormous emergencies in terms of health facilities, infrastructure and manpower. As a result, cases multiplied every single day with an increasing number of Covid-19 related death cases. The State government falls under various hurdles with the issues of Covid-19 with regards to the safeguard of the situation. In this regard, with the increasing rate of active cases, the government has initiated the extension of Community Covid Care Centre (4Cs) in various localities for isolating the covid-19 patients under the care and guidance of the Task Force. As the State resumes complete lockdown by mid-April 2021, it has hugely impacted the socio-economic conditions of the people in the worst manner. During the second wave since April 2021, there are 16,016 cases are being recorded so far which covers $78.16 \%$ of the total cases found in the State. ${ }^{(11)}$

However, as relaxation soon curled up regarding SOP on Covid-19 by the State governments in mid-June, there appears to have been a surge in covid cases. Thus, as a result after 18 days of relaxation, Mizoram has no other option but falls under the complete lockdown period again from $19^{\text {th }}$ July. For instance, based on the empirical analysis, it is evident that people are not careful enough whilst rules are not abiding accordingly. Besides, the government and executives are likely inefficient in implementing and executing the SOPs up to par. Meanwhile, the majority of the States in India is now at a declining rate while Northeast India and Mizoram, in particular, is now experiencing an alarming rate of covid-19 cases. So far, Mizoram has recorded 42,083 total covid-19 cases, while the active case is 13,065 , deaths -157 and recovered- 28,861 as of 5 Aug 2021. (12) Mizoram has recorded the highest covid-19 cases reported in a day on $25^{\text {th }}(1,369), 26^{\text {th }}$ $(1,118)$ and $28^{\text {th }}(1,100)$ cases respectively. (13)

\section{Government and Civil Society Organizations on Covid19}

Ever since the outbreak of covid19, there have been an immense involvement and contribution given by Civil Society Organisations alongside the government. From the initial stages, the government have given the opportunity in welcoming the voices and opinions given by the CSOs especially Churches and the Young Mizo Association (YMA) with regards to framing the policy of SOP on Covid-19. The government has also taken efforts in setting up a Task Force which mainly consists of voluntary members ie; the Local Level Task Force (for urban areas) and the Village Level Task Force (for rural areas) in every part of the State. This force is established for the purpose to undertake extensive measures in law and orders for the safety of the people under the instructions of government SOPs in their respective areas and also to help the less privileged in their communities during the COVID crisis. ${ }^{(14)}$

The task force has operated as a vital means on behalf of the State government in terms of executing and exercising government instructions under SOPs. They acted as a watchdog for the government where-in tracking and tracing of contact persons by Covid19 patients have been done largely by the task force. They have assumed a significant factor in handling law and orders in every town and cities respectively. The surge of the second wave which is more likely serious than before has brought back the Task Force in the spotlight. With the increasing rate of covid19 cases daily, the government has organised in setting up Community Covid Care Centre (CCCC) in various localities especially in Aizawl under the efforts and responsibilities taken by the task force.

The effects of mass increased in covid19 cases has heavily demanded the needs of manpower in various Community 
care centres. At this juncture, nurses and individuals have voluntarily stepped up to sacrifice their time for Community Care Centre which reveals a true spirit of humanitarian values of the Mizo. Meanwhile, the government has devoted the State Referral Hospital at Zoram Medical College (ZMS) as a dedicated hospital for Covid-19 patients besides several Covid Care Centre for quarantine and isolation for Covid patients have been set up under the care of the government.

Regarding the crisis of the Covid19 pandemic, the government has emphasised Testing, tracking, and treatment. Apart from this, since the arrival of the Covid-19 vaccine, the State government has immensely prioritized giving out vaccination drives to the people. It has been reported that 7,01,646 vaccines have been availed out of which 1,09,868 have taken complete doses (Vanglaini, daily newspaper dt. $16^{\text {th }}$ July 2021). ${ }^{(15)}$ In addition to this, Health Minister of Mizoram Dr R. Lalthangliana had stated that Mizoram has ranked $6^{\text {th }}$ position in giving out the most vaccine in India, during a meeting with Officials at Secretariat Conference Hall on July 17, 2021. Recently, due to the rapid increase in covid-19 cases, the government has also taken initiative in undertaking mass testing of samples within Aizawl city areas. For instance, this has appeared to be very effective in fighting against the spread of covid19 hence treatment of positive cases identified can be also done in an early manner.

The effects of Covid-19 and lockdown have heavily impacted the socioeconomic aspects of the people more likely to daily wage seekers in particular. Due to several lockdowns and certain restrictions issued by the government SOP on Covid19, several families have faced an enormous amount of hardship with no income being available. In this regard, the government has established a Relief Fund for the people under Chief Minister Relief Fund (CMRF). Under this, various groups, families and individuals have opened up in donating funds to CMRF. In addition, at the community level donations have been offered by localities to the task force for relief measures.

Generally, the covid-19 has most affected in Aizawl city where this has resulted in a shortage of essential needs in terms of fresh vegetables etc. At this point, to ease these problems, villages from several parts of Mizoram have come into action by willingly supply fresh vegetables from their farm to Aizawl city. This has shown the togetherness and unity of the Mizos' in supporting one another against Covid19 and proved that the government is not alone in this.

\section{METHODS AND MATERIALS}

In the light of Covid-19 issues, the essence of the study is to examine and understand governance on Covid19 in Mizoram. It stresses how the government and various organizations have given efforts in this situation and how the policy being adopted by them has had an impact on the people so far. It also emphasizes the issues and challenges of governance policy on Covid-19 for further references. The study was descriptive while data is collected from both primary and secondary sources. Primary sources were based on empirical analysis and questionnaire collected through online survey method while secondary sources include articles, journals, newspapers and internet. Findings are based on an online survey method that was conducted with a sample size of 500 and the universe of the study is Aizawl, Mizoram.

\section{STATISTICAL METHODS}

Data was analysed by employing descriptive and quantitative research. The study highlighted the issues and challenges of governance on COVID-19 through the multiple responses and analysed the outcome which further push the study in a significant manner. 


\section{RESULTS}

The study is conducted within Aizawl city (Aizawl being with highest cases and worst affected within Mizoram) concerning the governance policy on Covid19. A questionnaire is applied by using Google form with a sample size of 500 and a simple random sampling technique is employed. Findings generated through multiple response analysis based on questionnaire as given below:

Table: Online survey response on Governance and COVID-19 in Mizoram

\begin{tabular}{|l|l|l|l|l|}
\hline Governance Policy & Good & Poor & Others & Total Respondents \\
\hline Govt. efforts in response to Covid19 issues & 304 & 49 & 147 & \multirow{2}{*}{500} \\
\cline { 2 - 5 } & $60.8 \%$ & $9.8 \%$ & $29.4 \%$ & \\
\hline Contribution and involvement of CSOs on governance & 264 & 10 & 226 & \multirow{2}{*}{500} \\
\cline { 2 - 4 } & $52.8 \%$ & $2 \%$ & $45.2 \%$ & \\
\hline Task Force on Covid19 & 461 & 10 & 226 & \multirow{2}{*}{500} \\
\cline { 2 - 4 } & $92.2 \%$ & $2 \%$ & $45.2 \%$ & \\
\hline Lockdown Policy & 190 & 40 & 270 & \multirow{2}{*}{500} \\
\cline { 2 - 4 } & $38 \%$ & $8 \%$ & $54 \%$ & \multirow{2}{*}{500} \\
\hline Administration and execution on Covid19 protocols & 30 & 140 & 330 & \multirow{2}{*}{} \\
\cline { 2 - 4 } & $6 \%$ & $28 \%$ & $66 \%$ & \multicolumn{2}{|l}{} \\
\hline
\end{tabular}

From the above table, the study has shown that the governance policy on Covid19 has positive and negative aspects. It is evident that $60.8 \%$ of the respondents think that the government endeavour towards the issues of the Covid-19 is satisfactory, whereas $29.4 \%$ are not satisfied with the government efforts. In addition to this, a large number of the respondents have argued that the government preparedness is weak and action is not taken firmly.

In response to Civil Society Organizations CSOs), $52.8 \%$ feel that their contribution and involvement towards governance on Covid19 is good while $45.2 \%$ fall in the category where they believed that CSOs are not involved enough nor representations from them is limited in governance feature.

Another interesting outcome is that majority of the respondents (92.2\%) strongly supported and favour the Task Force organization. It is highly regarded as one of the best policies initiated by the State during Covid19. On the other hand, $45.2 \%$ thinks that the organization and set up of Task Force's powers and functions should be more appropriate.

The Lockdown policy imposed by the government has provided various opinions and implications. Amongst the respondents, $54 \%$ hold the opinion that continuous and frequent lockdown is not the best solution where it has led to socio- economic disadvantages in the society. However, they also believed that lockdown to a certain extent is essential to prevent the spread of the virus. On the other hand, 38\% supported the lockdown policy as it is the only major solution in this matter.

Lastly, with regards to the administration and execution process, $66 \%$ have argued that the government is not efficient enough in carrying out its policy for an effective result. They have argued that the government relied too much on the Task Force where it does not utilize enough of its government employees in terms of execution and maintenance of law and order. Moreover, they felt that the government is not transparent enough in handling the Relief fund and how it is allocated and distributed to the public.

\section{DISCUSSION}

The major essence of the study was to understand and examined governance on COVID-19, throwing light from Mizoram State perspective. Generally, during COVID-19, governance policy was reflected in the Standard Operating Procedure (SOPs) provided by the Government after due consultation from various representatives. As Covid-19 has proved to be one of the greatest and most unexpected challenges to the government of the world. It has been seen that various studies have been conducted concerning 
governance and its response on COVID-19. Given the similarities of the challenges encountered, one study has provided that strong and effective multilevel-governance is essential and the success of the response greatly depends on the active participation of all actors of society, as regards not only complying with confinement measures but also the direct involvement in initiatives that support or complement the action of public bodies. ${ }^{(16)}$ Thus, studies have shown that the response to COVID-19 has required increased efforts in terms of multilevel governance, with authorities at all levels of government being involved. Ensuring coordination, concertation, cooperation and communication between them has been crucial to the effective handling of the crisis.

A similar study also found that the response to COVID-19 highly emphasises the need of openness and transparency which are the detrimental components of democratic governance. The public has the right to be informed and to be provided with up-to-date, transparent and reliable information on the pandemic and the measures to tackle it. This is also a matter of accountability to counterbalance the fact that governments and local authorities sometimes need to adopt emergency measures with a lower level of public consultation as would normally be expected. (16) Concerning to governance and its response to Covid-19, another study has also argued that Covid-19 task forces are government only. Civil society and community groups not being engaged in primary discussions, neither are social workers, child development specialists, human rights lawyers, and many other people whose experiential and vocational expertise are particularly relevant in terms of societal rights, and groups affected by isolation measures. Civil society and community groups do not seem to be consulted at all. ${ }^{(17)}$ Besides one notable exception was that women perspectives and voices seemed to be less involved in taking the decision making perhaps while large number of females are at the front line staffs. Thus, more transparency is needed for governance to be more efficient and accountable.

It is recognised that the information is not complete nor up to date given the extremely fast-paced dynamic of the Covid19 outbreak as well as the response measure. Hence, study is based on broad range of publicly available information analysed through the online survey for the current study. However, based on the study analysed, it has given a glimpse picture on how governance response on the Covid-19 in Mizoram has been experienced. In this regard, one may strongly opined that Who, How and Which of the decision-making has reached and has consequences in the longterm.

\section{CONCLUSION}

After all, Covid19 has a ripple effect on humankind in general. Governments and various organizations endeavours against Covid19 is extremely intense. As Covid19 is a new thing to all people, certainly there are limitations involved in the procedures. Till today, Covid vaccines have not been proved that they are cent per cent secure enough to prevent one against the virus. Therefore, no government has not come up with an effective solution other than wearing a mask, social distancing and frequent handwash (covid appropriate behaviour). Thus, the responsibility falls in the hands of every individual to live by the rules for everyone's safety. On the other hand, it is the sole duty of the government to provide health facilities and enforce safety measures for its people. Thus, there can be major differences between active government and weak government in this regard.

The Govt. of Mizoram has also played a crucial role in the governance policy on Covid19, where it has done remarkable work in the process through the support of various organizations. More importantly, more transparency is needed regarding who decision-making bodies are listening to as a basis for their decisions. 
Now more than ever, the voices of those who are at risk of getting left behind need to be heard. Apparently, this virus is assumed to exist long enough along with human beings, therefore, for the survival of an individual, one needs to work and function daily. Thus, by keeping that in mind, Mizoram in particular where the economy is weak and not self-sufficient, the State government and official experts have to adopt new methods and strategies besides "lockdown" for the well-being of the people. Governments must recognise the multidimensional effects and needs of society during this Covid-19 crisis and consult more broadly and across disciplines, within health and beyond health, based on a true multisectoral paradigm.

\section{Acknowledgement: None}

\section{Conflict of Interest: None}

\section{Source of Funding: None}

\section{REFERENCES}

1. Organizations IL. COVID-19 and the world of work Country policy responses. [Internet]. 2021 [updated 2020 April 6; cited 2021 July 20]. Available from: HYPERLINK "http://www.ilo.org" http://www.ilo.org .

2. Deori U, Konwar G. Impact of COVID-19 in North Eastern States of India. Int J Health Sci Res.2020; 10(6):213-217.

3. Arshed N, Meo MS, Farooq F. Empirical Assessment of Government Policies and Flattening of the COVID19 curve. Journal of Public Affairs. 2020; e2333:2-22.

4. Worldometer. COVID Live Update. [Internet].2021 [updated 2021 August 20; cited 2021 Aug. 5]. Available from: HYPERLINK

"http://worldmeters/coronavirus.info" http://worldmeters/coronavirus.info .

5. Pandey A, Saxena NK. Effectiveness of Government Policies in Controlling COVID-19 in India.[Internet].International Journal of Health Services. 2020; 0(0)1-8.

6. Govt. of Mizoram. Study on COVID-19 Lockdown and its Economic consequences for the State of Mizoram. [Internet]. 2020 [updated 2020 May 3; cited 2021 June 15]. Available from: HYPERLINK

"http://www.planning.mizoram.gov.in" http://www.planning.mizoram.gov.in .

7. Soutik B. COVID-19: How India failed to prevent a deadly second wave. [Internet]. 2021 [updated 2021 April 18 ;cited 2021 July 12]. Available from: HYPERLINK "http://www.bbc.com" http://www.bbc.com

8. The Lancet COVID-19 Commission India Task Force. Managing India's Second COVID-19 Wave: Urgent Steps. [Internet]. 2021 [updated 2021 April 14;cited 2021 June 19]. Available from: HYPERLINK "http://www.static1.squarespace.com" http://www.static1.squarespace.com .

9. Welfare MoHaF, Govt. of India. COVID-19 Vaccination update. [Internet]. 2021 [updated 2020 Oct. 16; cited 2021 Aug. 5]. Available from: HYPERLINK "http:www.mohfw.gov.in" http:www.mohfw.gov.in .

10. Govt. of India. Updates on COVID-19. [Internet].2021 [updated 2021 Aug.22; cited 2021 Aug. 5]. Available from: https://www.mygov.in/covid-19.

11. Mizo Daily Vanglaini. Covid-19 leng thawh hnihna chhungin Hripui vei mi 16016 hmuh a ni tawh. [Internet].2021 [updated 2021 August 21; cited 2021 July 3]. Available from: HYPERLINK "http://www.vanglaini.org" http://www.vanglaini.org .

12. Directorate of Information \& Public Relations , Govt. of Mizoram. Mizoram COVID-19 Update. [Internet]. 2021 [updated;cited 2021 Aug. 5]. Available from: HYPERLINK

"http://www.dipr.mizoram.gov.in" http://www.dipr.mizoram.gov.in .

13. Mizo Daily Vanglaini. July-ah hripui vei 18,433 hmuh a ni. [Internet].2021 [updated 2021 August 21;cited 2021 Aug. 2]. Available from: HYPERLINK "http://www.vanglaini.org" http://www.vanglaini.org .

14. Harikrishnan U, Sailo GL. Mizo Youth and the COVID Lockdown life: A gender comparison. International Journal of Research and Review. 2020; 7(8): 221-225.

15. Mizo Daily Vanglaini. Covid vaccine pekah Mizoram parukna. [Internet].2021 [updated 2021 Aug. 21;cited 2021 Aug. 2]. Available from:

HYPERLINK 
"http://www.vanglaini.org" http://www.vanglaini.org .

16. Council of Europe. Democratic Governance and COVID-19.[Internet]. 2020 [updated 2020 Dec. 16; cited]. Available from: https://www.rm.coe.int.

17. Rajan D, Maike V, Koch KJ, et.al. Governance and the Covid-19 response: A call for more inclusive and transparent decision making. British Medical Journal Global Health. 2020; 5(5): 1-9.

How to cite this article: Sailo L. COVID-19 and governance in Mizoram: issues and challenges. International Journal of Research and Review. 2021; 8(8): 673-681. DOI: https://doi.org/10. 52403/ijrr.20210889 